Türkiye Jeoloji Bülteni
Geological Bulletin of Turkey
$64(2021) 233-248$
doi: $10.25288 /$ tjb.865944

\title{
Uludağ'ın (Bursa) Güneybatısındaki Jeotermal Kaynak ve Madensularının Kökenine Jeokimyasal Bir Yaklaşım
}

A Geochemical Approach to the Origin of Geothermal and Mineral Waters Southwest of Uluda $\breve{g}$ Mountain (Bursa)

\author{
Nizamettin Şentürk ${ }^{1}$ D, Halim Mutlu2 ${ }^{\text {ID }}$ \\ ${ }^{1}$ Madensuyu Üreticileri Derneği (MASUDER), Ankara \\ ${ }^{2}$ Ankara Üniversitesi, Jeoloji Müh. Bölümü, Gölbaşı Yerleşkesi, Ankara
}

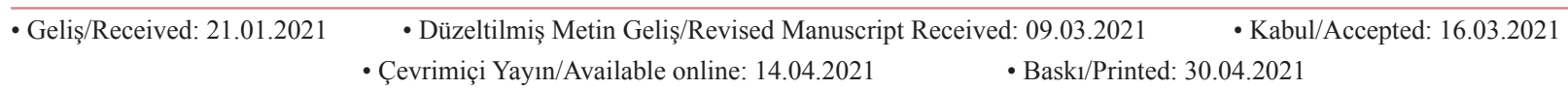

Araştırma Makalesi/Research Article Türkiye Jeol. Bül. / Geol. Bull. Turkey

Öz: Bu çalışmada, Uludağ’ın (Bursa) güneybatısındaki jeotermal kaynaklar ile maden sularının hidrojeokimyasal özellikleri ve kökensel ilişkileri incelenmiştir. Termal suların sıcaklıkları $37-64,5^{\circ} \mathrm{C}$ maden sularının sıcaklıkları ise $15,6-22,5^{\circ} \mathrm{C}$ arasında değişmektedir. Toplam çözünmüş madde miktarı (TDS) 451-2.026 mg/l arasında ölçülmüştür. Örneklerin pH değerleri sıcak sular için 7,1-7,3 arasında maden suları için daha asidik karakterde olup 6,2-6,7 aralığındadır. Sıcak sular Na-Ca- $\mathrm{HCO}_{3}$ fasiyesi ile temsil edilirken maden suları $\mathrm{Mg}-\mathrm{Na}-\mathrm{Ca}-\mathrm{HCO}_{3}$ tip özellik sergiler.

Bursa mineralli sularının trityum içerikleri 0,34 ile 5,96 TU arasında değişmektedir. Trityum sıcak sular için 0,341,95 TU arasında, maden suları için ise 1,57'den 5,46 TU'ya kadar değişmektedir. Bu sonuçlar akışkanların büyük bir kısmının modern sular olduğuna işaret etmektedir. Örneklerin $\delta^{18} \mathrm{O}$ değeri \%o-11,08 ile -7,97 (VSMOW) arasında $\delta \mathrm{D}$ değerleri ise \%o-73,81 ile -57,64 (VSMOW) arasında değişmektedir. Duraylı izotop bileşimleri Küresel ve Akdeniz Meteorik Su Çizgileri arasında kalan Bursa termal ve maden suları meteorik kökenlidir.

Bursa mineralli sularında çözünmüş inorganik karbonda $\left(\mathrm{HCO}_{3}\right)$ ölçülen $\delta^{13} \mathrm{C} \%$ o-15,3 ile $+10,12$ (VPDB) arasındadır. Sıcak suların karbon izotop bileşiminin maden sularına göre yaklaşık \%15 düşük olması bu sulardaki karbonun organik madde kaynaklı olduğunu gösterir. Maden sularında çözünmüş karbon ise denizel kireçtaşlarından türemiştir. Döteryum-yükseklik ilişkisi kullanılarak Bursa sıcak sularının 1180-2300 m arasında bir rakımdan itibaren beslendikleri bulunmuştur.

Anahtar kelimeler: Bursa, hidrojeokimya, izotop, jeotermal kaynak, maden suyu, Uludağ.

Abstract: In this study, hydrogeochemical characteristics and the origin of geothermal springs and mineral waters southwest of Uludağ (Bursa) Mountain were investigated. Temperatures of thermal waters are 37-64.5 ${ }^{\circ} \mathrm{C}$ and those of mineral waters range from 15.6 to $22.5^{\circ} \mathrm{C}$. Total dissolved solid (TDS) content of waters is in the range of 451 to $2026 \mathrm{mg} / \mathrm{l}$. The $\mathrm{pH}$ of mineral waters (6.2 - 6.7) is much more acidic than thermal waters (7.1 - 7.3). Thermal waters are represented by $\mathrm{Na}-\mathrm{Ca}-\mathrm{HCO}_{3}$ facies type, while mineral waters are $\mathrm{Mg}-\mathrm{Na}-\mathrm{Ca}-\mathrm{HCO}_{3}$ type.

Tritium measured in the Bursa mineral waters is 0.34 to 5.96 TU. Thermal waters (0.34 to 1.95 TU) have lower tritium content than mineral waters (1.57 to 5.46 T). These results indicate that most of studied fluids are regarded as modern waters. $\delta^{18} \mathrm{O}$ of samples is -11.08 to $-7.97 \%$ (VSMOW) and $\delta D$ values are in the range of -73.81 to $-57.64 \%$ o (VSMOW). Stable isotope compositions of Bursa mineral water are located between Global and Mediterranean Water Lines, indicating meteoric origin.

*Yazışma/Correspondence: nizamettinsenturk@gmail.com

(C) $2021 \mathrm{JMO}$ Her hakkı saklıdır/All rights reserved http://tjb.jmo.org.tr http://dergipark.gov.tr/tjb 
$\delta^{13} \mathrm{C}$ values measured in dissolved inorganic carbon $\left(\mathrm{HCO}_{3}\right)$ are between -15.3 and $+10.12 \%$ (VPDB). Carbon isotope compositions of thermal waters are about 15\% lower than those of mineral waters, implying that carbon in thermal springs is derived from an organic source. Carbon in mineral waters originates from marine limestones. Using the deuterium-altitude relationship, the recharge zone for Bursa mineral waters was at 1180-2300 m.

Keywords: Bursa, Geothermal spring, hydrogeochemistry, isotope, mineral water, Uludağ.

\section{GíRiș}

Avrasya ve Afrika plakalarının Mesozoyik'ten itibaren birbirlerine yakınlaşması ve buna bağl1 olarak bu plakalar arasındaki küçük kıtasal parçacıkların çarpışması, rotasyonu ve deformasyonu Alp-Himalaya dağ kuşağında yer alan Türkiye'de geniş yayılımlı magmatizma ve tektonik hareketlerin ortaya çıkmasına neden olmuştur (Dewey ve Şengör, 1979). Söz konusu kıtasal blokların sınırları genç volkanikler ve aktif faylar ile kuşatılan sismik kuşaklar şeklindedir. Anadolu'daki jeotermal sahaların büyük bir kısmı bu kuşaklar üzerindeki NeojenKuvaterner volkanizması ve ana faylar boyunca görülür. Örneğin, Doğu Anadolu bölgesinde jeotermal kaynaklar çok sayıda aktif fay sistemi (Çaldıran ve Kağızman fayları gibi) ve Neojen volkanizması (ör. Nemrut, Süphan, Tendürek ve Ağrı Yanardağları) ile ilişkilidir (Aydın vd., 2020). İç Anadolu bölgesindeki sıcak suların büyük çoğunluğu tarihsel olarak aktif olan yanardağların (ör. Hasandağ) çevresinde yer alırken, açılma rejiminin hüküm sürdüğü ve bunun sonucunda kabuğun incelmiş olduğu Batı Anadolu'da ise jeotermal kaynaklar daha çok grabenleri (B. Menderes, Simav, Alaşehir) sınırlayan fay sistemleri boyunca ortaya çıkmışlardır (Mutlu ve Güleç, 1998). Deprem odak noktalarının çok derinde yer aldığ 1 Kuzey Anadolu Fay Zonunda (KAFZ), doğrultu-atımlı faylar sicak suların pek çok alanda yüzeye ulaşmasında önemli rol oynamıştır (de Leew vd., 2010). Ancak genç magmatik sistemlerin KAFZ boyunca çok sinırlı bulunması akışkan sıcaklıklarının düşük olmasına yol açmıştır (Süer vd., 2008).

KAFZ'nun güney kolu Yenişehir-BursaManyas-Gönen-Pazarköy güzergâhını takip ederek Edremit körfezine ulaşır. Bu hat boyunca, termal suların sıcaklıkları fay zonunun diğer kısımlarındaki kaynaklara göre nispeten daha yüksektir (Mutlu, 2007). Bununla birlikte, Bursa ilinin güneyinde yer alan Uludağ' 1 n eteklerinde çok sayıda maden suyu çıkışı mevcuttur. Türkiye maden suyu üretimimin yaklaşık yarısı bu bölgede yapılmaktadır. Uludağ yükselimini kuzeyden sınırlayan ve halen aktif olan normal bileşenli D-B doğrultulu Bursa Fayı ve Uludağ'ın güneyinde İnegöl yöresi diri fayları (Şaroğlu vd., 1987) boyunca sıcak su kaynakları yer alır. Bursa ili ve çevresindeki sıcak suların jeokimyasal özellikleri bilinmesine karşın (ör. Tut Haklıdır, 2013), Uludağ maden suları ile termal suların ilişkisine yönelik detaylı bir araştırma bulunmamaktadır. Literatürdeki söz konusu boşluğu doldurmak amaciyla, bu çalışmada, Uludağ'ın güneybatısındaki ve kuzeydoğusundaki sıcak ve maden sularının hidrojeokimyasal özellikleri ile duraylı izotop sistematikleri incelenerek kökensel ilişkileri ortaya konmuştur.

\section{MALZEME VE YÖNTEM}

Uludağ sıcak ve mineralli su kaynaklarından 2020 Mart ayında 11 adet maden suyu ve 2 adet sicak su, 1 adet çeşme suyu örneği toplanmıştır. Suların pH, elektriksel iletkenlik, çözünmüş oksijen, TDS ve sicakl1k gibi fiziko kimyasal parametreleri Lovibond SD 335 Multi modeli ile örnekleme noktasında ölçülmüştür (Şekil 1a). Anyon-katyon, izotop ve trityum analizleri için örnekler sırasıyla $250 \mathrm{ml}, 500 \mathrm{ml}$ ve 1 litrelik HD-polietilen kaplara toplanmıştır. Maden suları işletme olan tesislerde suyun üretime girdiği noktalardan, diğerlerinde ise kuyu başı veya kaynaktan örneklenmiştir (Şekil 1b). Sıcak sular kaplıca tesislerinden toplanmıştır. 

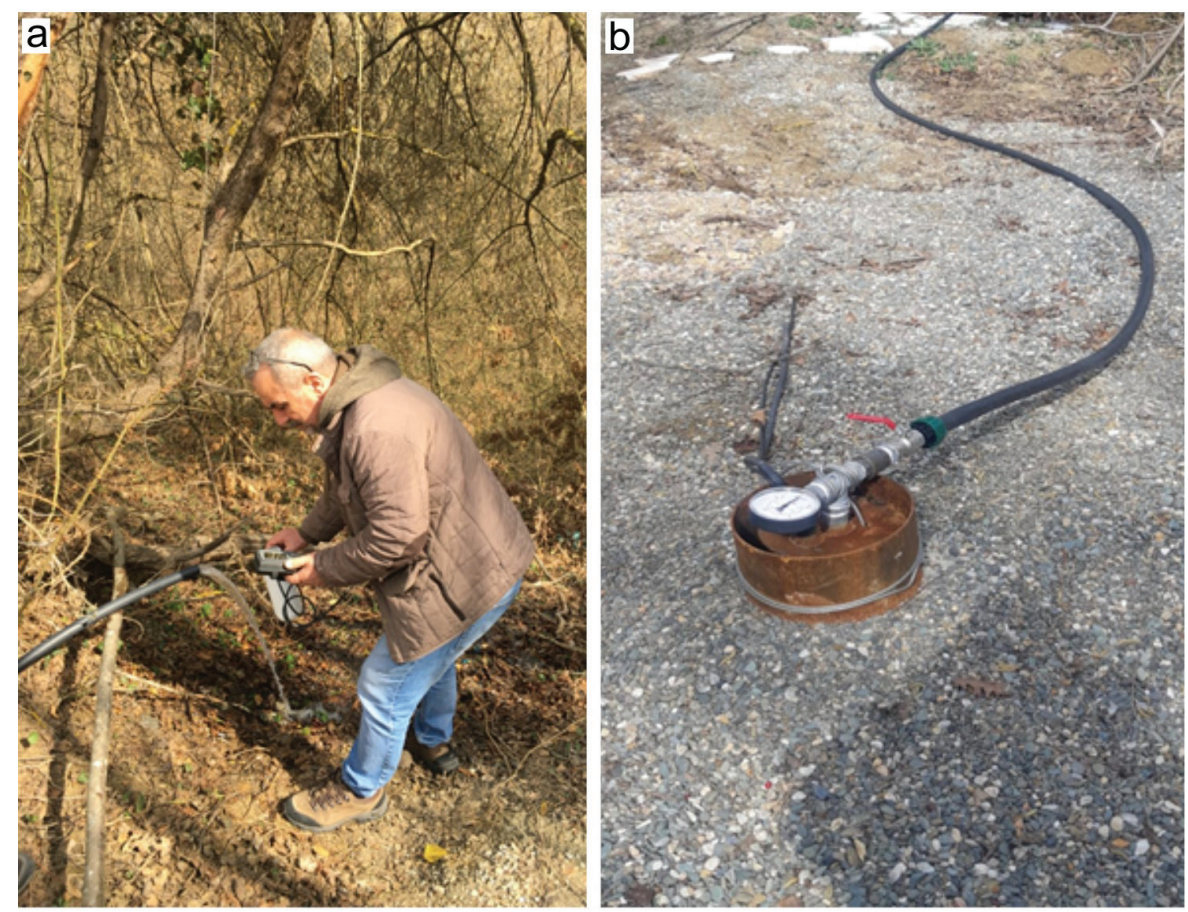

Şekil 1. a) Çaybaşı maden suyu. Kaynaktan üretim sı̆̆ bir kuyu vasıtasıyla yapılmaktadır, b) İnegöl maden suyu kaynağına ait kuyubaşı manometresi

Figure 1. a) Çaybaşı mineral water. Production from the spring is made from a shallow well, $\boldsymbol{b})$ Wellhead manometer for İnegöl mineral water spring.

Örneklerin majör iyon analizleri Uludağ İçecek Ar-Ge Merkezi laboratuvarlarında (Yenice, Bursa) yapılmıştır. Bikarbonat titrasyon yöntemiyle tespit edilmiş, diğer iyon analizleri ise iyon termal iletkenlik dedektör (TCD) bağlant1lı kromatografi ile gerçekleştirilmiştir. Analiz edilene kadar soğuk ortamda $\left(+4{ }^{\circ} \mathrm{C}\right.$ 'de) saklanan örnekler gözenek çap1 $0,45 \mu \mathrm{m}$ olan membrandan geçirilerek filtre edilmiştir. Örneklerin metal analizleri için elektrotermal atomik absorpsiyon spektroskopisi (ET-AAS) yöntemi kullanılmıștır. Cıva ise hidrür buhar1-AAS yöntemi ile bulunmuştur. Örneklerin anyon-katyon dengesi $\% 5$ civarındadır.

Trityum $\left({ }^{3} \mathrm{H}\right)$ analizleri Hacettepe Üniversitesi-Su Kimyası ve Çevresel Trityum Laboratuvarında Quantulus 1220 model beta sintilasyon spektrometre sistemi ile analiz edilmiştir. Analiz hassasiyeti 0,3 trityum birimidir (TU).
Suların oksijen-hidrojen ve kireçtaşlarının karbon-oksijen izotop analizleri Orta Doğu Teknik Üniversitesi-Merkezi Laboratuvarı'nda Delta Plus XP duraylı izotop oranı kütle spektrometresi ile ölçülmüştür. Sular için VSMOW olarak belirtilen sonuçların standart sapması $\delta^{18} \mathrm{O}$ ve $\delta \mathrm{D}$ için sırasıyla $\leq 0,3 \%$ o ve $\leq \%$ o3'tür. 0,2 - 0,4 mg ağırlıktaki karbonat örnekleri \%99 saflıktaki ortofosforik asit ile $70{ }^{\circ} \mathrm{C}$ 'de yaklaşık iki saat tepkimeye bırakılmıştır. Tepkime sonucunda açığa çıkan $\mathrm{CO}_{2}$ gazı izotoplarına ayrılması için kütle spektrometresine yollanmıştır. Analizlerde "NBS19 Limestone (NIST)" ( $\delta^{13} \mathrm{C}: \% 01,95$ ve $\delta^{18} \mathrm{O}$ : \%o-2,20) standart olarak kullanılmıştır. Sonuçlar \%o cinsinden VPDB'ye (Vienna Pee Dee Belemnite) göre belirlenmiştir. $\delta^{13} \mathrm{C}$ ve $\delta^{18} \mathrm{O}$ izotop oranlarına ilişkin $1 \sigma$ hata payları \%o, ${ }^{\prime}$ 'yi aşmamaktadır. 


\section{BÖLGESEL JEOLOJİSI}

Bat1 Anadolu, Tetis okyanusal litosferinin kuzeye dalmasıyla başlayan ve Paleojen'de gerçekleşen kıta-kıta çarpışması ile bir araya gelen her biri belirgin stratigrafik, yapısal ve metamorfik özellik sergileyen çok sayıda kıtasal levhadan meydana gelmiştir (Şengör ve Y1lmaz, 1981; Okay, 1989). İnceleme alanının da içinde bulunduğu bölge, üç önemli tektonik birlikten oluşmaktadır. Ofiyolit kenet kuşağıyla ayrılan ve birbirleriyle tektonik ilişkileri olan bu birlikler, Bursa'nın kuzeyinde İstanbul Zonu, güneyde Tavşanlı Zonu ve ortada Sakarya Zonu olarak adlandırılmıştır (Şengör ve Yılmaz 1981; Okay 1987). Sakarya Zonu, Geç Triyas'ta metamorfizma geçirmiş kırıntılı ve volkaniklerden oluşan bir temelden yapılı olup Jura-Eosen yaşlı sedimanter birimler tarafından uyumsuz olarak örtülüdür. Sakarya Zonunun güneyi İzmir-Ankara kenedi ile sınırlanmıştır. Kenet zonunun güney kısmında yer alan AnatolidTorid bloğu Paleozoyik kırıntılıları ile bunların üzerine gelen Mesozoyik yaşlı masif platform karbonatlarını kapsar (Okay vd., 1998). Bölgedeki temeli oluşturan Paleozoyik yaşıı Uludağ Karışı̆̆ 1 şist, mermer, amfibolit, gnays ve granitlerden oluşmaktadır (Ketin, 1947). Bursa ve civarı Paleozoyik-Kuvaterner zaman aralığındaki metamorfik, ofiyolitik, volkanik ve plütonik birimlerle temsil edilmektedir.

Örneklenen kaynakların lokasyonları esas alınarak çalışma bölgesi 4 kısma ayrılmıştır (Şekil 2 ve 3). Çaybaşı kaynak grubunun bulunduğu alanda temeldeki Paleozoyik yaşılı Uludağ Karışığı şist, mermer, amfibolit, gnays ve granitlerden oluşmaktadır (Ketin, 1947). Karışık içerisindeki şistler alacalı renkli olup yer yer mermer ve serpantinit ile ardalanmalıdır. Mermerler gribeyaz renkli, ince orta tabakalı ve tektonik etkiler nedeniyle bloklu haldedir. Bölgedeki en geniş yayılım gösteren birim olan Üst Kretase yaşı ofiyolitlik melanj Üst Jura-Alt Kretase yaşlı bir aşınma yüzeyi üzerine yayılmıştır (Bingöl vd.,1973). Bu birimin tabanında dünit, peridodit ve piroksenitler ile kromit yatakları görülür. Çaybaşı bölgesinde, Neojen Triyas yaşlı birimler üzerine uyumsuz olarak gelmektedir. Kuvaterner alüvyon ve traverten çökelleri ile temsil edilir. Alüvyonlar özellikle Nilüfer deresi boyunca sellenme ile yuvarlanmış irili ufaklı kırıntılı malzemeden meydana gelmektedir. Alüvyonun kalınlığ1, Bursa ovasında 80-200 m arasında değişmekte olup yaylım alanı ise yaklaşık $200 \mathrm{~km}^{2}$ dir. Ova alüvyonları genellikle iri blok, çakıl ile kumdan oluşur. Nilüfer deresi boyunca alüvyonun kalınlığ 1 15 metreye ulaşmaktadır.

İnegöl maden suyu kaynaklarının bulunduğu alanda Neojen yaşlı gölsel kireçtaşları geniş yayılım gösterir (Şekil 2). Oylat Kaplıcasının bulunduğu alanda ise, temeldeki Paleozoyik yaşlı metamorfik kayaçlar (mikaşist, mermer ve kristalize kireçtaşları) ile temsil edilen Uludağ Karışığ1 üzerine uyumsuz olarak konglomera, kiltaş1, kumtaş1 ve kireçtaşından oluşan Eosen çökeller gelir. En üstte ise Kuvaterner yaşlı traverten yer alır (Şekil 3).

Aslanlı sicak suyu beyaz-pembe renkli mikritten oluşan kısmen metamorfizmaya uğramış mermerlerden yüzeye ulaşır. Bu birimin yaklaşık kalınlığı 300-350 m arasında değişmektedir (Şekil $3)$.

Genel olarak bir değerlendirme yapılacak olursa; serpantin ve kireçtaşı bloklarından oluşan Triyas yaşlı Karakaya Formasyonu Uludağ Karışığı üzerine gelmektedir (Bingöl vd., 1973). Kireçtaşı blokları bol kırık ve çatlaklı yapı gösterir. $\mathrm{Bu}$ formasyonu breş, konglomera ve kumtaşlarından oluşan Eosen yaşlı Kalabakkaya Formasyonu örtmektedir. Gölsel kireçtaşlarından oluşan Neojen sedimanları bu birimlerin üzerinde görülür. 


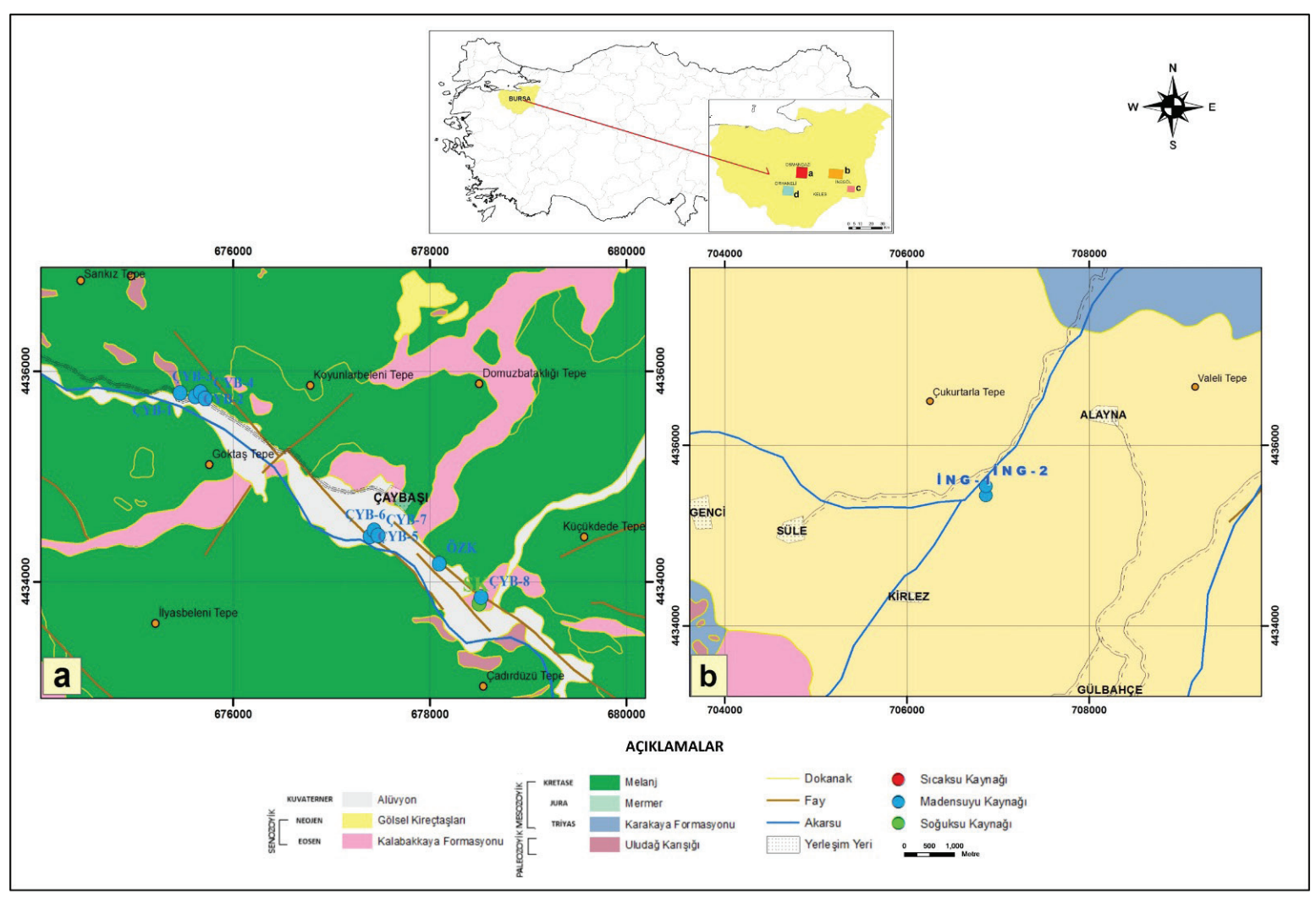

Şekil 2. İnceleme alanlarının yer bulduru ve jeoloji haritaları. a) Çaybaşı çevresi, b) İnegöl çevresi (jeoloji haritaları Ergül, 1980'den revize edilmiştir).

Figure 2. Location and geological maps of the study areas. a) Çaybaşı area, b) İnegöl area (geological maps revised from Ergül, 1980).

Çalışma alanı, kuzeybatı Türkiye'de tektonik olarak aktif bir bölgede yer almaktadır. Kuzey Anadolu Fayı ile yakından ilişkili çok sayıda fay mevcuttur. Türkiye deprem haritasına göre 1. derece deprem kuşağında yer alan bölgede tarihsel dönemlerde ve son yüz yılda yoğun deprem aktivitesi kaydedilmiştir (Ateş vd., 2009). İncelenen kaynakların yüzeye çıkışları büyük ölçüde tektonik hatlar tarafından denetlenir. Özellikle bölgenin güneyinde yer alan maden suları Nilüfer vadisindeki faya bağlı gelişen kırık ve çatlaklar boyunca yüzeye ulaşmaktadır. Ancak bu sular alüvyonun altında bulunduğundan mineralli suların üretilmesi alüvyonda sığ kuyuların açılmasıyla mümkün olabilmektedir (Şentürk, 2006). Uludağ Karmaşı̆̆ 1 içerisindeki granit ve mermerler, Karakaya Formasyonuna ait kireçtaşı blokları ve Aslanlı kaplıcası civarında geniş yayılım gösteren Jura yaşlı mermerler tektonizmanın etkisiyle kırıklı ve çatlaklı yapı göstermeleri nedeniyle iyi bir rezervuar kayaç özelliği taşırlar. Neojen birimlerinin kalınlıkları 500-600 m arasında olup çok az yeraltı suyu içerirler. Bu birimlerdeki killi-siltli seviyeler örtü kaya olarak düşünülebilir.

Bursa ilinde DSİ tarafından açılmış sığ kuyularda statik su seviyesinin 0 - 44 m arasinda değiştiği belirlenmiştir. Nilüfer çayı yakınlarında ise statik seviye yüzeye yakındır. Uludağ'ın büyük bölümümün gnays ve mikaşist gibi geçirimsiz birimlerden oluşması nedeniyle, ovadaki yeraltı suyu yağmur ve eriyen kar sularının yüzeysel akışa geçmesi ile beslenmektedir. 


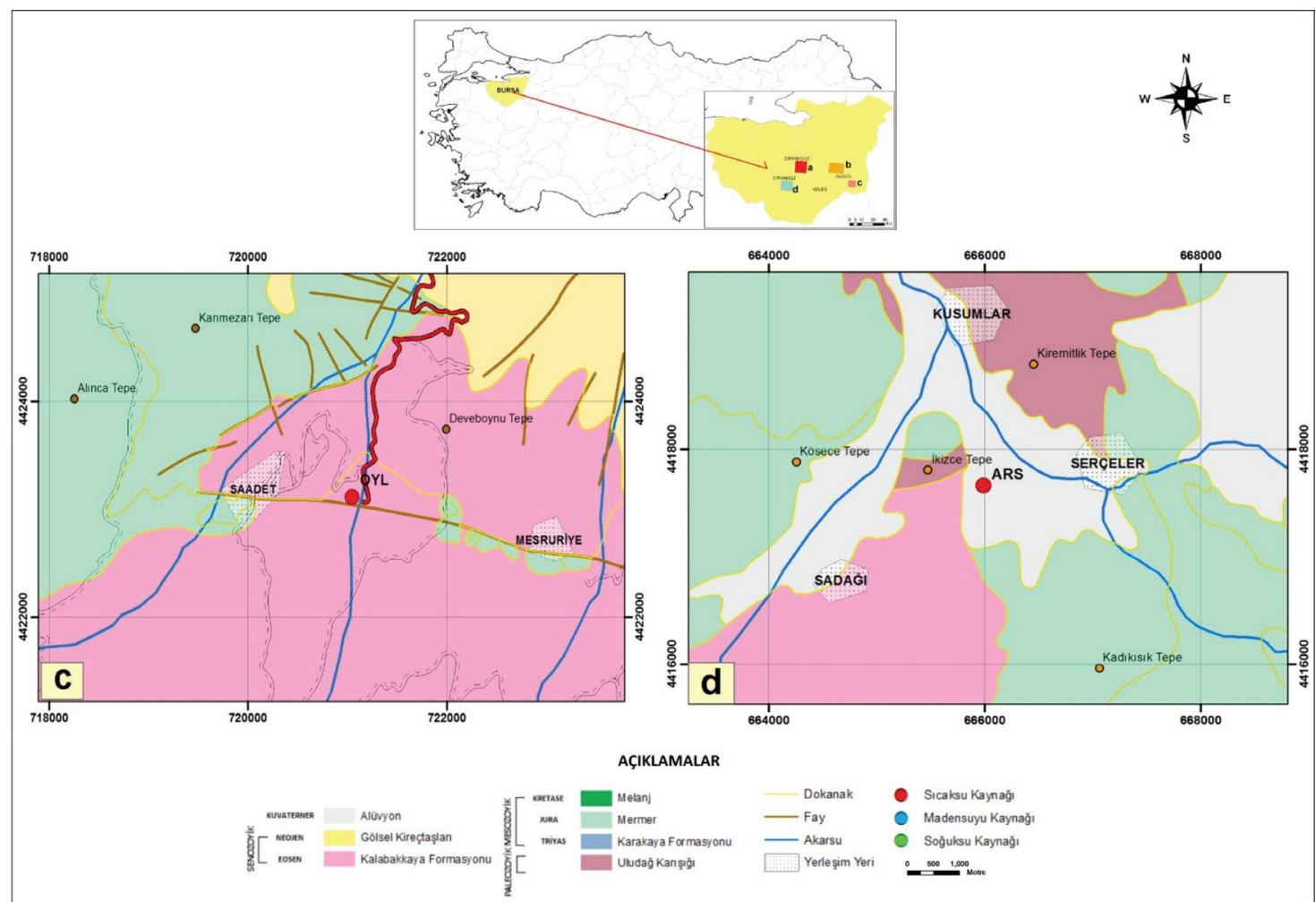

Şekil 3. İnceleme alanlarının yer bulduru ve jeoloji haritaları. c) Oylat Kaplıcası, d) Aslanlı Kaplıcası (jeoloji haritaları Ergül, 1980'den revize edilmiştir).

Figure 3. Location and geological maps of study areas c) Oylat hot spring, d) Aslanlı hot spring (geological maps revised from Ergül, 1980).

\section{BULGULAR}

\section{Su Kimyası}

Uludağ'ın güney batısındaki jeotermal kaynak ve maden sularının, sıcaklık, elektriksel iletkenlik, tuzluluk, toplam çözünmüş katı madde ve pH değerleri kaynak başında ölçülmüş olup, topluca Çizelge 1' de verilmiştir.

Jeotermal suların sicaklıkları $37^{\circ} \mathrm{C}$ ve 64,5 ${ }^{\circ} \mathrm{C}$ 'dir. Maden sularının sıcaklıkları ise 15,6 - 22,5 ${ }^{\circ} \mathrm{C}$ arasında değişmektedir. Suların elektriksel iletkenlikleri 746 ile $2.276 \mu \mathrm{s} / \mathrm{cm}$ arasındadır. Tuzluluk değerleri ise 0,1 - 1,2 ppt arasında olup, toplam çözünmüş madde miktarı (TDS) 451 1770 mg/l arasında ölçülmüştür. Örneklerin pH değerleri sıcak sular için 7,1 - 7,3 arasında maden suları için (İNG-1 nolu örnek hariç: 7,54) daha asidik karakterde olup 6,21 - 6,75 aralığındadır.
İnceleme alanında 2 adet jeotermal kaynak (sicak su), 11 adet maden suyu (mineralli su) ve 1 adet soğuk su kaynağı (çeşme) olmak üzere toplam 14 su örneğinden kimyasal analiz yapılmıştır. Alınan su örneklerinin kimyasal analiz sonuçları Çizelge 2'de verilmektedir.

IAH (1979) sinıflamasina göre, incelenen sicak sular $\mathrm{Na}-\mathrm{Ca}-\mathrm{HCO}_{3}$ tipinde olup maden sularının bileşimi ise $\mathrm{Na}-\mathrm{Mg}-\mathrm{Ca}-\mathrm{HCO}_{3}$ ağırlıklıdır. Soğuk su dışında, örneklerin $\mathrm{Na}^{+}$ve $\mathrm{Ca}^{2+}$ konsantrasyonları sirasiyla 19,9 - 690 ve 7,9 - 217,4 $\mathrm{mg} / \mathrm{l}$ arasında geniş bir aralıkta değişmektedir. Sulardaki en baskın iyon olan $\mathrm{HCO}_{3}^{-1} 130-1.807$ $\mathrm{mg} / \mathrm{l}$ arasındadır. $\mathrm{SO}_{4}^{-2}$ konsantrasyonları sicak sular ve maden suları için sırasıyla 103 - 280 ve 12 - 433 mg/l olarak ölçülmüştür. Klor derişimleri 7 - $128 \mathrm{mg} / \mathrm{l}$ arasında geniş bir aralıktadır. 
Çizelge 1.İnceleme alanındaki sıcak su ve madensularının fizikokimyasal özellikleri.

Table 1. Physicochemical characteristics of thermal and mineral waters in the study area.

\begin{tabular}{cccccccccc}
\hline $\begin{array}{c}\text { Kaynak } \\
\text { Cinsi }\end{array}$ & $\begin{array}{c}\text { Örnek } \\
\text { No }\end{array}$ & \multicolumn{2}{c}{ Koordinatlar } & Y ̈̈̈kseklik & T $\left({ }^{\circ} \mathbf{C}\right)$ & $\begin{array}{c}\text { EC } \\
(\boldsymbol{\mu} \mathbf{s} / \mathbf{c m})\end{array}$ & $\begin{array}{c}\text { Tuzluluk } \\
(\mathbf{p p t})\end{array}$ & $\begin{array}{c}\text { TDS } \\
(\mathbf{m g} / \mathbf{l})\end{array}$ & $\mathbf{p H}$ \\
\hline \multirow{2}{*}{ Sicak Su } & OYL & 4423112 & 721054 & 706 & 37,0 & 846 & 0,3 & 451,5 & 7,30 \\
& ARS & 4417662 & 665992 & 417 & 64,5 & 2004 & 0,8 & 2026 & 7,10 \\
\hline \multirow{5}{*}{ ÇYB-1 } & 4435790 & 675465 & 466 & 16,9 & 926 & 0,3 & 1333 & 6,38 \\
& ÇYB-2 & 4435758 & 675619 & 485 & 16,0 & 877 & 0,1 & 1630 & 6,37 \\
& ÇYB-3 & 4435800 & 675672 & 495 & 18,8 & 1377 & 0,8 & 1014 & 6,21 \\
& ÇYB-4 & 4435738 & 675721 & 493 & 20,3 & 2130 & 1,2 & 1500 & 6,42 \\
& ÇYB-5 & 4434431 & 677396 & 539 & 17,1 & 1180 & 0,7 & 903 & 6,51 \\
& ÇYB-6 & 4434486 & 677437 & 541 & 19,0 & 1160 & 0,4 & 910 & 6,72 \\
& ÇYB-7 & 4434438 & 677479 & 540 & 22,5 & 1165 & 0,5 & 980 & 6,30 \\
& ÇYB-8 & 4433852 & 678528 & 654 & 16,9 & 926 & 0,3 & 712 & 6,73 \\
& ÖZK & 4434171 & 678099 & 576 & 18,7 & 746 & 0,6 & 1009 & 6,75 \\
& İNG-1 & 4435443 & 706867 & 450 & 15,6 & 1373 & 0,9 & 1090 & 7,54 \\
& İNG-2 & 4435543 & 706868 & 440 & 16,3 & 2276 & 1,4 & 1770 & 6,96 \\
\hline Soğuk su & SK & 4433791 & 678506 & 648 & 16,8 & 631 & 0,4 & 760 & 7,84 \\
\hline
\end{tabular}

Çizelge 2.İncelenen suların iyon konsantrasyonları $(\mathrm{mg} / \mathrm{l})$.

Table 2. Ion concentrations of studied waters $(\mathrm{mg} / \mathrm{l})$.

\begin{tabular}{|c|c|c|c|c|c|c|c|c|c|c|}
\hline $\begin{array}{c}\text { Kaynak } \\
\text { Cinsi }\end{array}$ & $\begin{array}{c}\text { Örnek } \\
\text { No }\end{array}$ & $\mathbf{N a}^{+}$ & $\mathbf{K}^{+}$ & $\mathbf{M g}^{2+}$ & $\mathbf{C a}^{2+}$ & $\mathrm{HCO}_{3}^{-}$ & $\mathrm{SO}_{4}^{2-}$ & $\mathrm{Cl}^{-}$ & $\mathbf{F}^{-}$ & Su Tipi (IAH) \\
\hline \multirow{2}{*}{ Sicak Su } & OYL & 19,9 & 2.48 & 7,2 & 123,8 & 130,1 & 280,2 & 7,1 & 0,61 & \multirow{2}{*}{$\begin{array}{c}\mathrm{Na}-\mathrm{Ca}-\mathrm{Mg}-\mathrm{SO}_{4}-\mathrm{HCO} \\
\mathrm{Na}-\mathrm{Ca}-\mathrm{SO}_{4}-\mathrm{HCO}_{3}\end{array}$} \\
\hline & ARS & 203,2 & 5,1 & 1,1 & 155,1 & 901,1 & 103,2 & 22,5 & 3,83 & \\
\hline \multirow{11}{*}{ Maden Suyu } & ÇYB-1 & 23,6 & 23,6 & 81,1 & 217,4 & 1130,1 & 37,2 & 34,9 & 0,4 & $\mathrm{Ca}-\mathrm{Mg}-\mathrm{HCO} 3$ \\
\hline & ÇYB-2 & 238,9 & 34,1 & 81,1 & 204,4 & 1678,1 & 53,9 & 42,6 & 0,5 & $\mathrm{Na}-\mathrm{Ca}-\mathrm{Mg}-\mathrm{HCO}_{3}$ \\
\hline & ÇYB-3 & 116,5 & 24,1 & 89,8 & 141,3 & 1203,1 & 35,6 & 19,5 & 0,5 & $\mathrm{Mg}-\mathrm{Ca}-\mathrm{Na}-\mathrm{HCO}_{3}$ \\
\hline & ÇYB-4 & 293,6 & 37,1 & 112,5 & 182,1 & 1807,2 & 22,1 & 66,3 & 0,5 & \multirow{4}{*}{$\begin{array}{c}\mathrm{Na}-\mathrm{Mg}-\mathrm{Ca}-\mathrm{HCO}_{3} \\
\mathrm{Na}-\mathrm{Mg}-\mathrm{HCO}_{3} \\
\mathrm{Ca}-\mathrm{Mg}-\mathrm{Na}-\mathrm{HCO}_{3} \\
\mathrm{Na}-\mathrm{Mg}-\mathrm{HCO}_{3}\end{array}$} \\
\hline & ÇYB-5 & 112,7 & 16,4 & 58,5 & 136,1 & 943,1 & 27,8 & 62,9 & 1,51 & \\
\hline & ÇYB-6 & 135,6 & 15,5 & 86,5 & 143,4 & 984,1 & 39,7 & 98,8 & 0,7 & \\
\hline & ÇYB-7 & 163,7 & 26,1 & 75,2 & 199,7 & 1305,1 & 35,3 & 90,7 & 2,4 & \\
\hline & ÇYB-8 & 28,8 & 3,5 & 91,1 & 110,7 & 829,6 & 12,1 & 25,1 & 0,1 & $\mathrm{Mg}-\mathrm{Ca}-\mathrm{HCO}_{3}^{3}$ \\
\hline & ÖZK & 43,6 & 5,3 & 114,4 & 70,3 & 872,1 & 34,8 & 22,6 & 0,6 & $\mathrm{Mg}-\mathrm{Ca}-\mathrm{HCO}_{3}$ \\
\hline & İNG-1 & 305,5 & 1,8 & 41,8 & 69,1 & 894,1 & 297,4 & 19,3 & 0,3 & $\mathrm{Na}-\mathrm{Mg}-\mathrm{HCO}_{3}-\mathrm{SO}_{4}$ \\
\hline & İNG-2 & 689,9 & 0,7 & 4,6 & 7,9 & 1012,1 & 433,4 & 128,1 & 0,6 & $\mathrm{Na}-\mathrm{Mg}-\mathrm{HCO}_{3}-\mathrm{SO}_{4}^{4}$ \\
\hline Soğuk su & SK & 0,8 & 0,08 & 120,5 & 9,9 & 554,8 & 42,1 & 34,9 & 0.7 & $\mathrm{Mg}-\mathrm{HCO}_{3}$ \\
\hline
\end{tabular}

Schoeller diyagramındaki (Schoeller, 1962) kimyasal bileşim desenleri incelenen suların yoğunluklu olarak kireçtaşları olmak üzere ofiyolit ve granit gibi magmatik kayaçlarla etkileştiklerine işaret etmektedir (Şekil 4). Çaybaşı köyü kaynaklarından ÇYB-1 örneği $\mathrm{Ca}-\mathrm{Mg}-\mathrm{HCO}_{3}$,
ÇYB-2 örneği Na-Ca-Mg-HCO ${ }_{3}$, ÇYB-3 örneği $\mathrm{Mg}-\mathrm{Ca}-\mathrm{Na}-\mathrm{HCO}_{3}$, ÇYB -4 örneği Na-Mg-Ca$\mathrm{HCO}_{3}$, ÇYB-5 ve ÇYB-7 örnekleri Na-Mg$\mathrm{HCO}_{3}$, ÇYB-6 örneği Ca-Mg-Na-HCO ${ }_{3}$ ve ÇYB8 ve ÖZK nolu örnekler ise $\mathrm{Mg}-\mathrm{Ca}-\mathrm{HCO}_{3}$ sular sınıfına girmektedir. SK örneğinin $\mathrm{Mg}-\mathrm{HCO}_{3}$ 
bileşimine sahip olması bu kaynağın ofiyolit birimi boyunca yüzeye boşalması ile uyumludur. İnegöl civarındaki İNG-1 ve İNG-2 suları ise $\mathrm{Na}-\mathrm{Mg}-\mathrm{HCO}_{3}-\mathrm{SO}_{4}$ su sinıfindadir. Aynı bölgede bulunan Oylat kaplica örneği (OYL) ise Na-Ca$\mathrm{Mg}-\mathrm{SO}_{4}-\mathrm{HCO}_{3}$, Orhaneli bölgesindeki Aslanlı kaplıcasından alınan ARS nolu örnek ise Na-Ca$\mathrm{SO}_{4}-\mathrm{HCO}_{3}$ karakterindedir. Sulardaki katyonanyon siralaması ARS, ÇYB-2, ÇYB-4, ÇYB1 ve ÇYB-2 örnekleri için $\mathrm{rNa}+\mathrm{rK}>\mathrm{rCa}+\mathrm{rMg}$ ve $\mathrm{rHCO}_{3}>\mathrm{rCl}+\mathrm{rSO}_{4}$ diğer örneklerde ise $\mathrm{rCa}+\mathrm{rMg}>\mathrm{rNa}+\mathrm{rK}$ ve $\mathrm{rHCO}_{3}>\mathrm{rCl}+\mathrm{rSO}_{4}$ şeklinde olup sodyum bikarbonatlı ve kalsiyum bikarbonatl suları işaret etmektedir. Örneklerin Schoeller diyagramındaki desenleri belirli bir gruplaşmanın olmadığını ve tüm suların büyük ölçüde benzer kimyasal özellikler taşıdığını göstermektedir (Şekil 4).

Bursa sularının kimyasal bileşimini denetleyen jeokimyasal süreçler Piper diyagramında (Piper, 1944) değerlendirilmiştir (Şekil 5). Ca-Mg- $\mathrm{HCO}_{3}$ bileşimine sahip ÇYB-1, ÇYB-8 ve ÖZK nolu sular muhtemelen karbonatlı birimleri yıkayarak yüzeye ulaşmışlardır. $\mathrm{Na}-\mathrm{HCO}_{3}$ karakterli İNG-
1 ve İNG-2 örneklerinin bileşimi feldispatların çözünmesi ile denetlenmiştir. OYL ve ARS sıcak suları başlangıçta $\mathrm{Ca}-\mathrm{HCO}_{3}$ bileşimli olmalarına karşın derin dolaşım vasıtasıyla $\mathrm{Cl}$ içerikleri göreceli olarak artmıştır (Aydın vd., 2020). Bu sulara ait yüksek sodyum konsantrasyonları da (Çizelge 2) su-kayaç etkileşim derecesinin nispeten yüksek veya yeraltı dolaşım süresinin uzun olduğunu teyit etmektedir.

\section{İzotop bileşimleri}

\section{Trityum}

Radyoaktif olması nedeniyle, trityum suların yeraltı dolaşım süresinin belirlenmesinde oldukça kullanışlıdır (Clark ve Fritz,1997). Trityum konsantrasyonu sı̆̆ dolaşımlı sularda yüksek iken derin dolaşımlı sularda düşüktür. Derin dolaşımdaki değer çoğunlukla sıfıra yakındır. İncelenen alandaki kaynakların trityum değerleri 0,34 ile 5,96 TU arasında değişmektedir (Çizelge 3). Trityum konsantrasyonu sicak sular için 0,34 1,95 TU arasında iken maden suları için 1,57'den 5,46 TU'ya kadar değişmektedir. Çeşme örneği

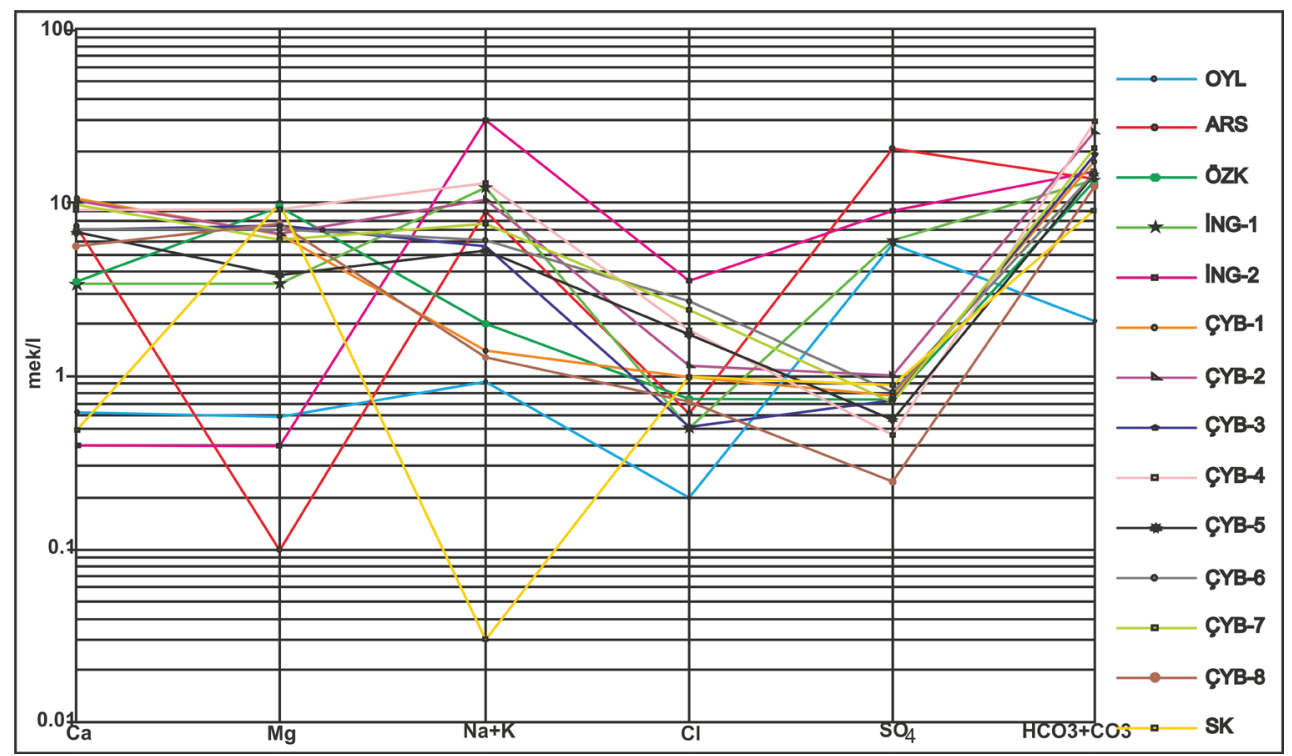

Şekil 4. Schoeller diyagramı (Schoeller, 1962).

Figure 4. Schoeller diagram (Schoeller, 1962). 


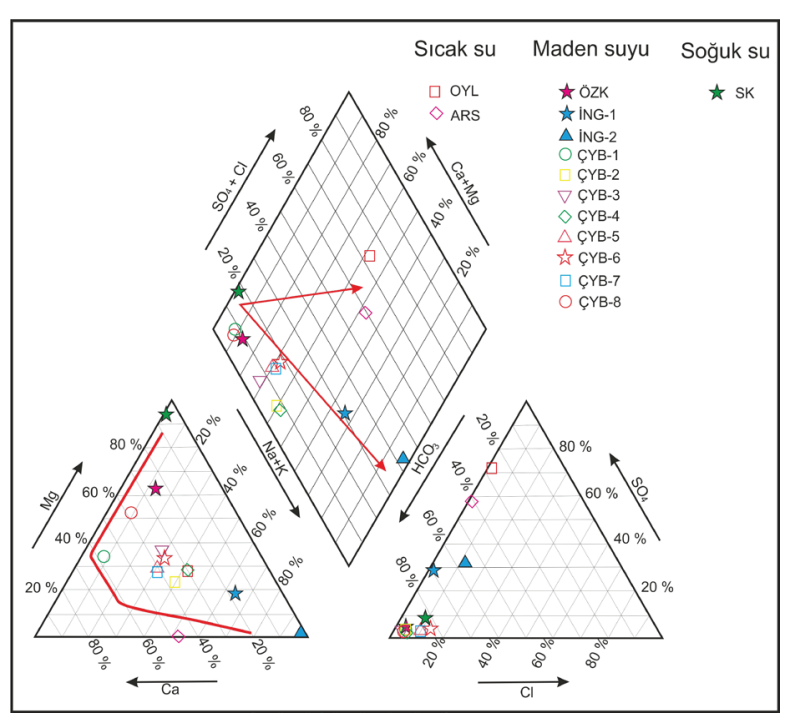

Şekil 5. Piper diyagramı (Piper, 1944).

Figure 5. Piper diagram (Piper, 1944).

(5,98 TU) incelenen sular arasında sirkülasyon süresi en düşük olan kaynaktır. Güncel yağış suyunun trityum değerinin 8,0 TU olduğu düşünülürse (Clark ve Fritz, 1997), suların büyük bir kısmının güncel sular olduğu söylenebilir.

Bursa sularının yeraltındaki dolaşım derinliği ile toplam çözünmüş madde içerikleri arasındaki ilişki elektriksel iletkenlik-trityum diyagramında incelenmiştir (Şekil 6). Örneklere ait düşük trityum değerleri yeraltı dolaşım süresinin ve/veya kayaçlarla etkileşim derecesinin arttığına işaret eder. Yüksek elektriksel iletkenlik (EC) değerleri de bu durumun göstergesidir. Güncel yağış suyundan itibaren bölgedeki en düşük trityum ve en yüksek EC değerlerine sahip örneklere (ARS, ÇYB-4 ve İNG-2) doğru bir karışım söz konusudur. Oylat (İnegöl) kaplıca örneğinin (OYL) göreceli yüksek ${ }^{3} \mathrm{H}$ içeriği söz konusu suyun sı̆̆ bir dolaşımda olması veya yeraltı suyu ile karışması ile açıklanabilir. Sonuç olarak, en düşük trityum bileşimi ile Aslanlı (ARS) suyunun bölgedeki en yaşlı akış süresine sahip suyu temsil etmektedir.

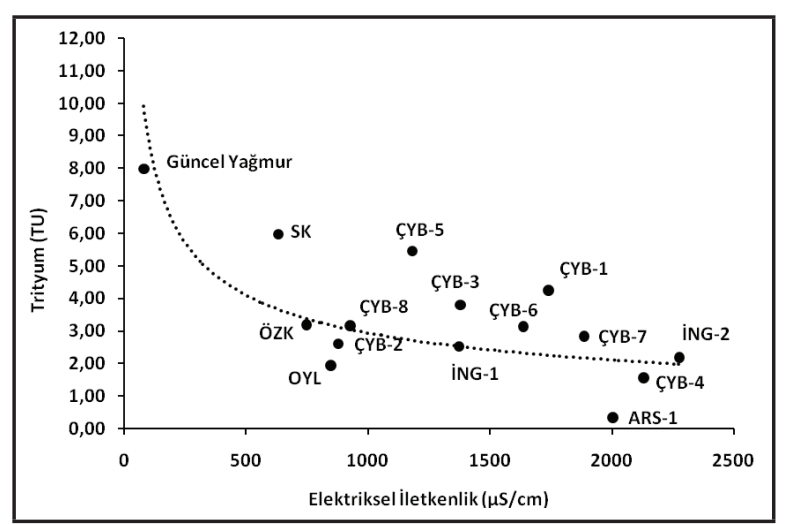

Şekil 6. Trityum değerlerine karşı elektriksel iletkenlik diyagram1.

Figure 6. Tritium vs. electrical conductivity diagram.

\section{Oksijen-hidrojen izotop bileşimleri}

Oksijen ve hidrojen duraylı izotopları hidrojeokimya çalışmalarında suların kökeni ve beslenme yüksekliğinin belirlenmesinde oldukça faydalı bir araçtır (Craig, 1961). Meteorik sular magmatik sulara göre hafif izotoplarca $\left({ }^{16} \mathrm{O}-{ }^{1} \mathrm{H}\right)$ zengin olup negatif $\delta^{18} \mathrm{O}$ ve $\delta \mathrm{D}$ değerlerine sahiptir (Clark ve Fritz, 1997). Artan sıcaklık ve ayrıca silikat ve karbonatlı kayaçlar ile gerçekleşen sukayaç etkileşimi sonucunda meteorik akışkanların özellikle oksijen izotop bileşimi pozitif yönde sapma gösterebilir. Bununla birlikte, hidrojenin kayaçların ana bileşenlerinden biri olmaması suların $\delta \mathrm{D}$ değerini önemli oranda etkilemez.

Bursa termal ve maden su örneklerinin oksijen-hidrojen izotop bileşimleri Çizelge 3'te verilmiştir. Örneklerin oksijen izotop $\left(\delta^{18} \mathrm{O}\right)$ değerleri \%o-11,08 ile -8,49 (VSMOW) arasında, hidrojen izotop $(\delta \mathrm{D})$ değerleri ise \%o-73,81 ile -57,64 (VSMOW) arasında değişmektedir (Çizelge 3). Genel olarak sıcak suların $\delta^{18} \mathrm{O}-\delta \mathrm{D}$ değerleri maden sularına göre daha düşüktür. Oksijen-hidrojen izotop grafiğinde (Şekil 7), Bursa termal ve maden sularının Küresel Meteorik Su Çizgisi $\left(\delta \mathrm{D}=8 \delta^{18} \mathrm{O}+10\right.$; Craig, 1961) ile Akdeniz Meteorik Su Çizgisi $\left(\delta \mathrm{D}=8 \delta^{18} \mathrm{O}+22\right.$; Gat ve Carmi, 1987) arasında kaldıkları görülür. $\mathrm{Bu}$ bulgular Bursa mineralli sularının meteorik kökenli olduklarını göstermektedir. 
Çizelge 3. Bursa bölgesinden alınan su ve kayaç örneklerinin duraylı izotop (\%) ve trityum analiz sonuçları.

Table 3. Results of stable isotope (\%o) and tritium analyses for water and rock samples collected from the Bursa region.

\begin{tabular}{cccccccc}
\hline $\begin{array}{c}\text { Kaynak } \\
\text { Cinsi }\end{array}$ & Örnek No & $\begin{array}{c}{ }^{3} \mathbf{H} \\
\mathbf{( T U})\end{array}$ & $\begin{array}{c}\delta^{18} \mathbf{O} \\
(\mathbf{V S M O W})\end{array}$ & $\begin{array}{c}\delta \mathrm{D} \\
(\text { VSMOW) }\end{array}$ & $\begin{array}{c}\delta^{13} \mathbf{C} \\
(\mathbf{V P D B})\end{array}$ & $\begin{array}{c}\delta^{13} \mathbf{C}(\mathbf{K c ̧ t}) \\
(\mathbf{V P D B})\end{array}$ & $\begin{array}{c}\delta^{18} \mathbf{O} \text { (Kçt) } \\
(\mathbf{V P D B})\end{array}$ \\
\hline Sicak Su & OYL & $1,95 \pm 0,46$ & $-10,87$ & $-68,98$ & $-0,27$ & 2,17 & $-8,02$ \\
\hline & ARS & $0,34 \pm 0,44$ & $-11,08$ & $-73,81$ & $-5,58$ & 2,17 & $-12,62$ \\
& ÇYB-1 & $4,26 \pm 0,48$ & $-9,42$ & $-65,42$ & 4,78 & & \\
& ÇYB-2 & $2,61 \pm 0,43$ & $-9,16$ & $-63,80$ & 4,72 & & \\
& ÇYB-3 & $3,81 \pm 0,47$ & $-9,36$ & $-69,71$ & 4,26 & 0,92 & $-2,99$ \\
& ÇYB-4 & $1,57 \pm 0,42$ & $-9,49$ & $-66,73$ & 5,64 & & \\
Maden Suyu & ÇYB-5 & $5,46 \pm 0,51$ & $-9,15$ & $-72,06$ & 6,23 & & $-15,94$ \\
& ÇYB-6 & $3,14 \pm 0,45$ & $-8,89$ & $-61,50$ & 10,12 & $-0,30$ & \\
& ÇYB-7 & $2,84 \pm 0,43$ & $-8,84$ & $-62,55$ & 9,81 & & \\
& ÇYB-8 & $3,17 \pm 0,46$ & $-9,70$ & $-57,64$ & 2,72 & & \\
& ÖZK & $3,19 \pm 0,44$ & $-9,12$ & $-59,89$ & 2,74 & & \\
\hline Soğuk Su & İNG-1 & $2,53 \pm 0,47$ & $-8,49$ & $-62,84$ & & & \\
\hline
\end{tabular}

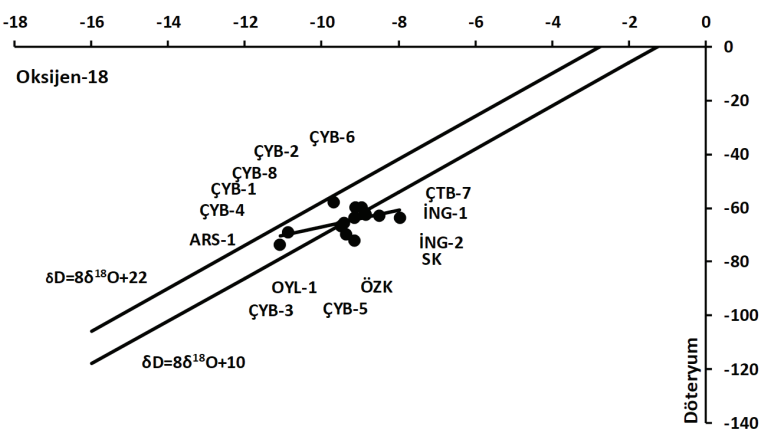

Şekil 7. Oksijen-hidrojen izotop grafiği.

Figure 7. Oxygen-hydrogen isotope graph.

Sicak suların (OYL ve ARS) oksijen-hidrojen izotop sistematiklerinin maden sularına göre belirgin şekilde düşük olması $\left(\delta^{18} \mathrm{O}\right.$ için $\sim \% 03$ ve $\delta \mathrm{D}$ için $\%$ 12) termal suların daha yüksek rakımlardan beslendiklerini göstermektedir. ING2 nolu maden su örneğinin $\delta^{18} \mathrm{O}$ değeri diğer sulardan \%o2 kadar pozitif sapma göstermiştir (Çizelge 3 ve Şekil 7). Bu suda ölçülen TDS içeriğinin bölgedeki en yüksek değer olması ING-
2 maden suyunun rezervuar kayaçlarla uzun süreli etkileşimde bulunduğunu ve böylece oksijen izotop bileşiminin arttığını doğrulamaktadır. Diğer sular için $\delta^{18} \mathrm{O}$ değerini belirgin ölçüde etkileyecek su-kayaç etkileşimi söz konusu değildir. Bununla birlikte, örneklerde gözlenen ufak çaplı izotop değişimlerinin beslenme yüksekliği farklılığından kaynaklandığı düşünülmektedir.

\section{Karbon izotop bileșimleri}

Karbonatlı kayaçların çözünmesi, atmosferik kökenli karbon ve toprak organik maddesinden açığa çıkan $\mathrm{CO}_{2}$ suda çözünmüş karbonun başlıca kaynaklarını oluşturur. Bu farklı rezervuarlardaki karbonun izotop bileşimi de $\left(\delta^{13} \mathrm{C}\right)$ oldukça değişkendir. Denizel kireçtaşlarının $\delta^{13} \mathrm{C}$ değeri \%o-3 ile +3 arasındadır. Buna karşın, organik kökenli karbon \%o-50'ye kadar uzanan oldukça düşük $\delta^{13} \mathrm{C}$ değerleri ile temsil edilir. Atmosferik ve manto kaynaklı karbondioksit ise \%o-7 ile -6 arasında dar bir aralıkta yer alır (Clark ve Fritz, 1997). 
Bursa mineralli sularında çözünmüş inorganik karbonda $\left(\mathrm{HCO}_{3}\right)$ ölçülen $\delta^{13} \mathrm{C}$ değerleri \%o-15,3 ile $+10,12$ (VPDB) arasında değişmektedir (Çizelge 3). Sicak suların (\%o-5,58 ile -0,27) karbon izotop bileşimi maden sularına (\%o-7,04 ile $+10,1)$ göre yaklaşık \%o15 düşüktür. Maden sularının büyük bir kısmının karbon izotop değerleri denizel kireçtaşları için önerilen aralıklar ile (\%o-3 ile +3 arasında) örtüşmektedir. Sıcak sular ile soğuk su örneği $(\%-15,3)$ ise organik madde kaynaklı karbon içermektedir.

Bursa mineralli sularının karbon izotop bileşimleri ile $\mathrm{HCO}_{3}$ konsantrasyonları arasında orta dereceli pozitif bir ilişki mevcuttur (Şekil 8). Suların karbonatlı kayaçları çözmesi sonucu sulardaki bikarbonat konsantrasyonu ve dolayısıyla $\delta^{13} \mathrm{C}$ değeri giderek artmıştır (Mutlu, 2007; Ak1llı ve Mutlu, 2018). Bölgedeki başlıca rezervuar kayacı oluşturan kireçtaşlarından elde edilen karbon izotop değerleri de bu durumu desteklemektedir.

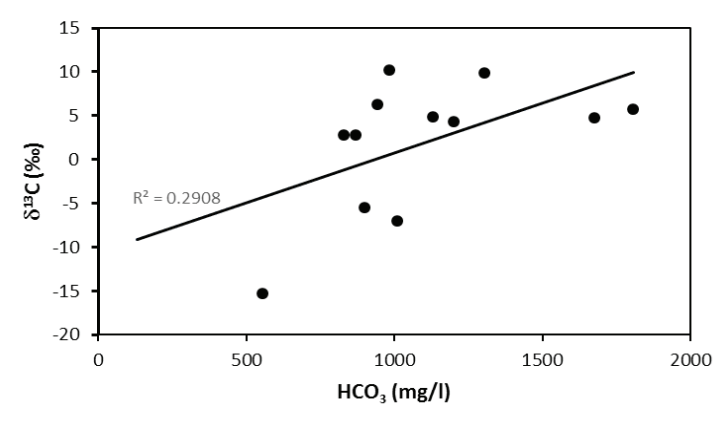

Şekil 8. Bursa mineralli suları için $\mathrm{HCO}_{3}-\delta^{13} \mathrm{C}$ ilişskisi.

Figure 8. $\mathrm{HCO}_{3}-\delta^{13} \mathrm{C}$ association for Bursa mineral waters.

Kireçtaşlarında ölçülen $\delta^{13} \mathrm{C} \%{ }^{0}-0,3$ ile 2,17 (VPDB) arasında dar bir aralıkta değişmektedir. Oylat kaplıca (OYL) ve ÇYB-3 maden suyunda belirlenen karbon izotop bileşimi aynı sahalardaki kireçtaşından elde edilen $\delta^{13} \mathrm{C}$ değerleri ile örtüşürken Aslanlı kaplıca kaynağı (ARS) ve ÇYB6 maden suyuna ait karbon izotop sistematikleri kireçtaşı eşleniklerinden sapma göstermektedir (Çizelge 3). Bu durum söz konusu sulardaki karbonun yüksek sıcaklıkta oluşmuş kayaçlardan (örneğin mermer) türediğini düşündürmektedir.

\section{TARTIŞMA}

\section{Maden Sularının Kökeni}

Maden sularının termal sularla kökensel açıdan ilişkili olduğu birçok çalışmada ortaya konmuştur (Truesdell vd., 1977; Fournier, 1979; Mutlu, 1998). Sicak suyun soğuması üç temel işlev vasıtasıyla gerçekleşir: kaynama, karışım ve kondüktif soğuma (Fournier, 1979; Truesdell 1991). Yüksek sıcaklıklı akışkanın ani basınç düşmesi sonucu kaynaması soğumaya neden olur. Bu işlev akışkandan buhar ayrılmasını sonuçladığı için kalıntı akışkandaki iyon derişimi artar. Termal akışkanın soğuk yeraltı suyu veya kendisinden düşük sıcaklığa sahip diğer sularla karışması ise soğuma ile birlikte iyon konsantrasyonunun azalmasına yol açar. Kondüktif (temas yolu ile) soğuma işlevi, termal suların yüzeye hareketi sırasında 1sılarını yan kayaçlara iletmesi prensibine dayanır. Ancak nispeten hızlı gerçekleşen bu süreç boyunca su-kayaç etkileşimi sınırlı ölçüde olduğundan termal suların iyon derişimi değişmez.

Maden sularının ortak özellikleri $\mathrm{HCO}_{3}$ $\left(\mathrm{CO}_{2}\right)$ konsantrasyonların yüksek buna karşıllı $\mathrm{pH}$ değerlerinin sıcak su eşleniklerine göre düşük olmasidır (Mutlu, 1998; Marques vd., 2006). $\mathrm{CO}_{2}$ bakımından zengin termal ve maden sularında, akışkanların kimyasal ve fiziksel özelliklerini etkileyen temel parametrenin sıcaklıktan ziyade karbondioksit olduğu belirtilmiştir (Criaud ve Fouillac 1986; Greber 1994). Su baskın sistemlerde $\mathrm{CO}_{2}$ 'in çözünürlüğü azalan sıcaklıkla arttığından bu tür sulardaki su-kayaç etkileşimi düşük sıcaklıkta gerçekleşir. Bu süreç suların $\mathrm{pH}$ değerini düşürmekle birlikte su-kayaç etkileşim derecesini arttırır (Marques vd., 2006).

Bursa maden sularının oksijen izotop $\left(\delta^{18} \mathrm{O}\right)$ değerlerinin sicak sulara göre $\sim \% 3$ fazla olması yüksek $\mathrm{CO}_{2}$ eşliğinde mermer ve silikatl kayaçlarla uzun süreli etkileşimde bulunduklarını 
işaret etmektedir. Stumm ve Morgan (1981) artan $\mathrm{CO}_{2}$ kismi basinc ile albit mineralinin çözünürlüğünün arttığını ortaya koymuşladır. Bursa mineralli sularında 2000 mg/l'ye kadar varan $\mathrm{HCO}_{3}$ konsantrasyonları sulardaki $\mathrm{P}_{\mathrm{CO} 2}$ değerlerinin yüksek olduğuna işaret etmektedir.

Helyum izotop bileşimindeki $\left({ }^{3} \mathrm{He} /{ }^{4} \mathrm{He}\right)$ değişimler farklı tektonik ortamlarda gerçekleşen kabuk ve manto kaynaklı uçucuların etkileşimlerin anlaşılmasında oldukça kullanışlıdır. İlksel kökenli (yerküre yığışımından arta kalan) olan ${ }^{3} \mathrm{He}$ halen mantodan salınım yapmaktadır. Buna karşın ${ }^{4} \mathrm{He}, \mathrm{U}$ ve Th minerallerinin radyoaktif bozunmas1 sonucu ortaya çıkar. Kabuk ve mantonun izotop bileşimlerinin oldukça farklı olması nedeniyle, kıtasal ortamlardaki doğal sularda yürütülen helyum izotop çalışmaları manto kökenli akışkanların kabuksal rezervuarlara eklenmesine yönelik önemli bilgi sağlar (Hilton vd., 2002). Helyum sulu akışkanlarda daha çözünür olduğundan buhar kaybı sırasında tercihli olarak buhar fazına katılır.

Bursa sicak sularından elde edilen helyum izotop $\left({ }^{3} \mathrm{He} /{ }^{4} \mathrm{He}\right)$ değerleri $(0,19-0,79 \mathrm{Ra})$ $\mathrm{CO}_{2}$ 'ce zengin maden sularına $(0,81$ - 1,36 Ra) göre daha düşüktür (Parlaktuna vd., 2008). Ancak her iki su tipinden de alınan bu değerler kabuksal litolojilerdeki radyojenik helyum üretiminden belirgin şekilde yüksektir (ortalama $\mathrm{RA}=0,05$; Farley ve Neroda, 1998; Barry vd., 2014). Kabuksal (0,05 Ra) ve manto kaynakl1 (8 Ra) helyum bileşenleri arasında basit ikili karışım düşünüldüğünde, Bursa sicak ve maden sularındaki mantosal helyum katk1s1 \%2,4 - 16,9 arasında bulunmuştur.

\section{Beslenme yüksekliği}

Oksijen ve hidrojen izotopları akış sırasında bileşimleri değişmediği veya bölümlenmedikleri varsayımıla beslenme yüksekliğinin belirlenmesinde kullanılabilir. Yağış suyuna ait izotop bileşiminin yükseklikle değiştiği (yükseklik etkisi) göz önüne alındığında izotop kompozisyonu bilinen herhangi bir suyun beslenme alanı tespit edilebilir (Clark ve Fritz, 1997). Beslenme zonlarının belirlenmesi için hem oksijen hem de hidrojen izotop verileri başarılı bir şekilde kullanılmaktadır (Giggenbach vd., 1983; James vd., 2000; Schürch vd., 2003; Aydın vd., 2020; Gökgöz vd., 2021). Önceki çalışmalarda 100 metrelik yükseklik artışı için $\delta^{18} \mathrm{O}$ ve $\delta^{2} \mathrm{H}$ içeriklerinin sırasıly $\% 00,15$ - 0,50 (VSMOW) ve $\%$ 1,0 - 4,0 (VSMOW) arasında azaldığ 1 ortaya konmuştur.

$\mathrm{Bu}$ çalışmada, su-kayaç etkileşiminin neden olacağı olası etkileri ortadan kaldırmak için beslenme yüksekliği hesaplarında oksijen izotoplar1 yerine hidrojen izotop verisi kullanılmıştır. Bursa mineralli suları için $\delta^{18} \mathrm{O}$ ve $\delta^{2} \mathrm{H}$ değerlerinin rakım ile değişimleri \%o $0,24 / 100$ $\mathrm{m}$ ve $\%$ 1,22/100 $\mathrm{m}$ olarak tespit edilmiştir (Tut Haklıdır, 2013). Bu veriler esas alınarak döteryum-yükseklik denklemi $\left(\delta^{2} \mathrm{H}=(-0,00432\right.$ x yükseklik) - 63,87) olarak bulunmuştur (Tut Haklıdır, 2007). Bu eşitlik kullanılarak incelenen sıcak ve maden suları için elde edilen beslenme yükseklikleri sırasıyla 1.180-2.300 m ve 660-1.890 $\mathrm{m}$ arasındadır (Şekil 9). Bu sonuçlar sıcak suların Uludağ'ın (2.540 m) daha yüksek alanlarından beslendiğini göstermektedir.

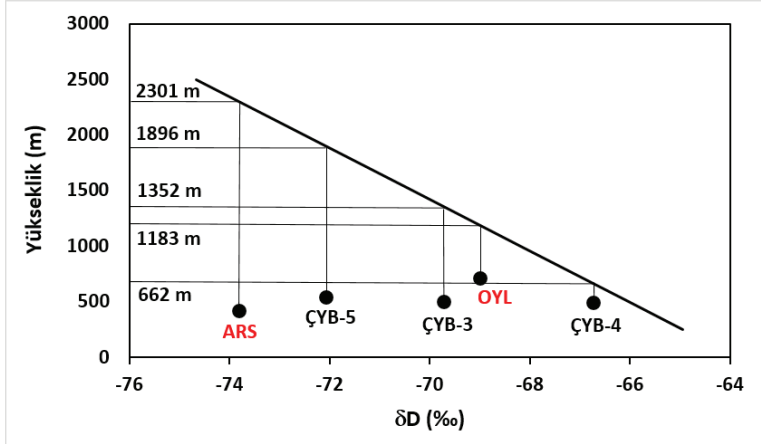

Şekil 9. Bursa mineralli suları için yükseklik- $\delta \mathrm{D}$ ilişkisi.

Figure 9. Elevation- $\delta D$ relationship for Bursa mineral waters. 


\section{SONUÇLAR}

Uludağ'ın güneybatısındaki jeotermal kaynaklar ile maden sularının toplam çözünmüş madde (TDS) içeriği 451-2.026 mg/l arasında geniş bir aralıktadır. Sicak sulara göre daha asidik karakterde $(\mathrm{pH}=6,2-6,7)$ olan maden suları düşük sıcaklık altında $\mathrm{CO}_{2}$ eşliğinde mermer ve silikatlı kayaçlarla uzun süreli etkileşim soncunda oluşmuşlardır. Bursa mineralli suları Na-Ca$\mathrm{HCO}_{3}$ ve $\mathrm{Mg}-\mathrm{Na}-\mathrm{Ca}-\mathrm{HCO}_{3}$ fasiyesleri ile temsil edilmektedir. Sularda ölçülen trityum sıcak sular için 0,34 - 1,95 TU arasında maden suları için ise 1,57'den 5,46 TU'ya kadar değişmektedir. Bu değerler akışkanların büyük bir kısmının güncel sular olduğunu göstermektedir.

Suların $\delta^{18} \mathrm{O}$ değerleri $\%$-11,08 ile $-7,97$ (VSMOW) arasında $\delta \mathrm{D}$ değerleri ise \%o-73,81 ile -57,64 (VSMOW) arasındadır. Oksijen-hidrojen sistematikleri Küresel ve Akdeniz Meteorik Su Çizgileri arasında kalan Bursa termal ve maden suları meteorik kökenlidir.

İnorganik karbonda $\left(\mathrm{HCO}_{3}\right)$ ölçülen $\delta^{13} \mathrm{C}$ $\%$ - 15,3 ile $+10,12$ (VPDB) arasindadir. Sicak suların karbon izotop değerleri organik madde kaynağına işaret ederken maden sularında çözünmüş karbon ise denizel kireçtaşlarından türemiştir. Döteryum değerleri esas alınarak Bursa sıcak sularının beslenme yüksekliği 1.180-2.300 $\mathrm{m}$ arasında bulunmuştur.

Türkiye'deki maden suyu üretiminin büyük bir kısmının Uludağ bölgesinde yapılması nedeniyle, yıllık su beslenme ve boşalım miktarlarının belirlenmesi sürdürülebilir üretim açısından büyük önem taşımaktadır.

\section{EXTENDED SUMMARY}

It was shown that thermal and cold mineral waters share a genetic link (Truesdell et al., 1977; Fournier, 1979; Mutlu, 1998). Cooling of thermal waters occurs by a combination of processes including boiling and conductive cooling of thermal water and mixing of thermal water with cold water (Fournier, 1979; Truesdell 1991). Boiling of high-temperature water due to a sudden pressure drop results in cooling which, in turn, gives rise to steam separation from the fluid and an increase in the ion concentration of the residual fluid. Conductive cooling is based on the principle that thermal waters transfer their heat to surrounding rocks along their route to the surface. However, TDS values of thermal waters remain almost unchanged since waterrock interaction occurs on a limited scale. It is a common feature of mineral waters that their $\mathrm{HCO}_{3}$ ( $\left.\mathrm{CO}_{2}\right)$ concentration is high, whereas $\mathrm{pH}$ values are lower than those of thermal waters (Mutlu, 1998; Marques et al., 2006). It waspointed out that carbon dioxide rather than temperature is the main parameter affecting the physicochemical characteristics of $\mathrm{CO}_{2}$-rich thermal and mineral waters. Since the solubility of $\mathrm{CO}_{2}$ increases with increasing temperature in water-dominated systems, water-rock interaction in these waters occurs at low temperatures. This process lowers the $\mathrm{pH}$ of waters but increases the degree of waterrock interaction (Marques et al., 2006).

Nearly half of the mineral water production in Turkey (775 million liters) is from the Bursa district, northwestern Turkey. Although mineral waters in this region have great potential, geochemical controls on these mineralized fluids have not been investigated. Therefore, in this study, various geochemical and water-rock interaction mechanisms responsible for the occurrence of Bursa thermal and cold mineral waters were examined. The material in the study comprised 11 mineral waters, 2 thermal waters and one cold water in the southwest and northeast parts of Uludağ mountain in the Bursa district. The pH, electrical conductivity, TDS and temperature of the waters were measured at the sampling sites.

Major ion, tritium and stable isotope $\left(\delta^{18} \mathrm{O}\right.$, $\delta D$ and $\left.\delta^{13} C\right)$ compositions of water samples and carbon-oxygen isotope values $\left(\delta^{18} O-\delta^{13} C\right)$ of carbonate rocks were measured. Temperatures of thermal waters are in the range of 37 to 64.5 ${ }^{\circ} \mathrm{C}$ and those of mineral waters vary from 15.6 to $22.5{ }^{\circ} \mathrm{C}$. Total dissolved solid (TDS) content of waters are between 451 and 2,026 $\mathrm{mg} / \mathrm{l}$. The $\mathrm{pH}$ of mineral waters (6.2 to 6.7) is more acidic than 
thermal waters (7.1 to 7.3). Thermal waters are represented by $\mathrm{Na}-\mathrm{Ca}-\mathrm{HCO}_{3}$ facies type, whereas mineral waters are $\mathrm{Mg}-\mathrm{Na}-\mathrm{Ca}-\mathrm{HCO}_{3}$ type.

Geochemical processes controlling the chemical composition of Bursa waters were examined on the Piper diagram (Piper, 1944) (Figure 3). Some of waters with $\mathrm{Ca}-\mathrm{Mg}-\mathrm{HCO}_{3}$ composition probably interacted with carbonate units. The composition of Inegöl waters (samples ING-1 and ING-2) with $\mathrm{Na}-\mathrm{HCO}_{3}$ type is controlled by feldspar dissolution. Moreover, some waters such as OYL and ARS initially had $\mathrm{Ca}$ $\mathrm{HCO}_{3}$ composition and their $\mathrm{Cl}$ content relatively increased as a result of deep circulation (Aydin et al., 2020). High $\mathrm{Na}$ concentration of these waters (Table 2) also supports a relatively high degree of water-rock interaction or much longer underground residence time.

Tritium content of shallow-circulating waters is high, whereas deep-circulating waters are represented by lower tritium values (nearly zero). Tritium concentrations of the studied waters are 0.34 to $5.96 \mathrm{TU}$ (Table 3). Tritium contents of thermal waters are $0.34-1.95 \mathrm{TU}$ and those of mineral waters are 1.57 to 5.46 TU. The relationship between circulation depth and total dissolved solid (TDS) content of Bursa waters was examined on an electrical conductivitytritium diagram (Figure 4). Low tritium contents of samples may imply longer residence time and/ or intense water-rock interaction. This is also supported by high electrical conductivity (EC) values of samples. There is mixing between modern precipitation and samples with the highest $E C$ values and the lowest tritium contents.

Oxygen and hydrogen isotope compositions are very helpful for investigating the origin of waters and discharge elevation (Craig, 1961). Meteoric waters are enriched in light isotopes $\left({ }^{16} \mathrm{O}-{ }^{1} \mathrm{H}\right)$ and have negative $\delta^{18} O$ and $\delta D$ values (Clark and Fritz, 1997). Because of interactions with silicate and carbonate rocks at high temperatures, the oxygen isotope composition of meteoric fluids shifts positively. Since hydrogen is not a major component in most silicate minerals, $\delta D$ values remain unchanged.
Oxygen and hydrogen isotope compositions of Bursa mineral and thermal waters are -11.08 to $-8.49 \%$ (VSMOW) and -73.81 to $-57.64 \%$ (VSMOW), respectively (Table 3). on the oxygen and hydrogen isotope graph (Figure 5), both types of waters plot between the Global Meteoric Water Line $\left(\delta D=8 \delta^{18} \mathrm{O}+10\right.$; Craig, 1961) and Mediterranean Meteoric Water Line $\left(\delta D=8 \delta^{18} O+22 ;\right.$ Gat and Carmi, 1987). These results imply that Bursa mineral and thermal waters have meteoric origin. In general, $\delta^{18} O-\delta D$ values of thermal waters are lower than those of mineral waters ( $3 \%$ for $\delta^{18} \mathrm{O}$ and $\sim 12 \%$ for $\delta D$ ) which indicates that thermal waters are recharged from higher elevations.

$\delta^{13} \mathrm{C}$ values of Bursa waters measured in dissolved inorganic carbon $\left(\mathrm{HCO}_{3}\right)$ vary from -15.3 to $+10.12 \%$ (VPDB) (Table 3). Carbon isotope compositions of thermal waters (from -5.58 to $-0.27 \%$ ) are about $15 \%$ o lower than those of mineral waters (-7.04 to $+10.1 \%$ ). Carbon isotope values of most mineral waters are consistent with the array proposed for marine limestones $( \pm 3 \%$ ). Carbon in thermal waters and the cold water sample (-15.3\%) has an organic source. There is a moderate correlation between $\delta^{13} \mathrm{C}$ values and $\mathrm{HCO}_{3}$ concentrations of Bursa mineral waters (Figure 6). As the waters dissolve the carbonate rocks, their bicarbonate contents and carbon isotope compositions are increased (Mutlu, 2007; Aklll and Mutlu, 2018). This finding agrees well with carbon isotope values for limestones, which comprise the main reservoir rocks in the region.

Oxygen and hydrogen isotope compositions can be used to estimate the recharge elevation of waters assuming that they are not modified or fractionated during the flow. Considering that isotope composition of rainwater changes with altitude, the recharge elevation of any water with known isotope composition might be estimated (Clark and Fritz, 1997). Both oxygen and hydrogen isotopes were successfully used for determination recharge zones (Giggenbach et al., 1983; James et al., 2000; Schürch et al., 2003; Aydin et al., 2020). In previous studies, with every $100 \mathrm{~m}$ elevation increase $\delta^{18} \mathrm{O}$ and $\delta^{2} \mathrm{H}$ are found to decrease 
0.15-0.50\%o (VSMOW) and 1.0-4.0\%o (VSMOW), respectively.

In this study, in order to eliminate possible effects of water-rock interaction, hydrogen isotope compositions were used for the recharge elevation estimation. In previous studies, the decrease in $\delta^{18} \mathrm{O}$ and $\delta^{2} \mathrm{H}$ values with elevations were found to be $0.24 \% / 100 \mathrm{~m}$ and $1.22 \% / 100 \mathrm{~m}$ (Tut Haklıdir, 2013) and the resulting deuteriumelevation equation is given as $\delta^{2} H=(-0.00432 x$ elevation) - 63.87 (Tut Haklidir, 2007). Based on this equation, the recharge elevations for Bursa thermal and mineral waters are 1,180-2,300 m and 660-1,890 $\mathrm{m}$, respectively. These results show that thermal waters are recharged from higher parts of Uludağ Mountain $(2,540 \mathrm{~m})$.

\section{KATKI BELIRTME}

Yazarlar örneklerin kimyasal analizlerine yönelik sağladığı olanak için Uludağ İçecek Türk A.Ş.'ye ve ayrıca görüş ve önerileriyle makaleye katkı sağlayan hakemlere teşekkürü borç bilirler.

\section{ORCID}

Nizamettin Şentürk (D https://orcid.org/0000-0002-2296-2441

Halim Mutlu (D) https://orcid.org/0000-0002-4100-1363

\section{KAYNAKLAR / REFERENCES}

Akıllı, H. ve Mutlu, H. (2018). Polatlı ve Haymana (Ankara) sıcak sularının kökenine yönelik kimyasal ve izotopik sinırlamalar. Yerbilimleri, 39(1), 41-64.

Aydın, H., Karakuş, H. \& Mutlu, H. (2020). Hydrogeochemistry of geothermal waters in eastern Turkey: geochemical and isotopic constraints on water-rockinteraction. Journal of Volcanology and Geothermal Research, 390, Article 106708. https:// doi.org/10.1016/j.jvolgeores.2019.106708

Ateş, Ş., Mutlu, G., Bulut Üstün, A., Özata, A., Özerk, O.C., Karakaya Gülmez, F., ve Osmançelebioğlu, R. (2009). Bursa İli ve Kentsel Alanların Yer Bilim Verileri (Derleme no: 11163). Maden Tetkik ve Arama Genel Müdürlüğü (yayımlanmamış).

Barry, P. H., Hilton, D. R., Füri, E., Halldórsson, S. A. \& Gronvold, K. (2014). Carbon isotope and abundance systematics of Icelandic geothermal gases, fluid sand subglacial basalts with implications for mantle plume-related $\mathrm{CO}_{2}$ fluxes. Geochimica et Cosmochimica Acta, 134, 74-99.

Bingöl E., Akyürek B. ve Korkmazer B. (1973). Biga Yarımadasının Jeolojisi ve Karakaya Formasyonun Bazı Özellikleri. Cumhuriyetin 50. Yılı Yerbilimleri Kongresi Ankara (s. 70-76).

Clark, I. D. \& Fritz, P. (1997). Environmental Isotopes in Hydrogeology. Lewis Publishers, New York.

Craig, H. (1961). Isotopic variations in meteoric waters. Science, 133, 1833-1834.

Criaud, A. \& Fouillac, C. (1986). Etude de seaux thermo minerales carbogaze uses du Massif Central Français. II. Comportment de quelquesmetaux en trace, de l'arsenic, de l'antimoine et dugermanium. Geochimica et Cosmochimica Acta, 50, 1573-82.

De Leew, G. A. M., Hilton, D. R., Güleç, N. \& Mutlu, H. (2010). Regional and temporal variations in $\mathrm{CO} 2 / 3 \mathrm{He}, 3 \mathrm{He} / 4 \mathrm{He}$ and $\mathrm{d} 13 \mathrm{C}$ along the North Anatolian Fault Zone, Turkey. Applied Geochemistry, 25, 524-539.

Dewey, J. F. \& Şengör, A. M. C. (1979). Aegean and surrounding regions: complex multiplate and continuum tectonics in a convergent zone. Geological Society of America Bulletin, Part I, 90, 84-92.

Ergül, E., Öztürk, Z., Akçaören, F. ve Gözler, M. Z. (1980). Balıkesir Ili-Marmara Denizi arasının Jeolojisi (Derleme No: 6760). Maden Tetkik ve Arama Enstitüsü (yayımlanmamış).

Farley, K. A. \& Neroda, E. (1998). Noble gases in the Earth's mantle. Annual Review of Earth and Planetary Sciences, 26, 189-218.

Fournier, R. O. (1979). Geochemical and hydrologic consideration sand theuse of enthalpy-chloride diagrams in the prediction of underground conditions in hot-spring systems. Journal of Volcanology and Geothermal Research, 5, 1-16.

Gat, J. R. \& Carmi, I. (1987). Effect of climate changes on the precipitation pattern sand isotope composition of water in a clima tetransition zone - case of the eastern Mediterranean Sea area. In S. I. Solomon, M. Beran, \& W. Hogg (Eds.), The Influence of Climate Changeand Climate Variability on the Hydrologic Regime and Water Resources (pp. 513523) IAHS Publications.

Giggenbach, W. F., Gonfiantini, R., Jangi, B. L. \& Truesdell, A. H. (1983). Isotopic and chemical composition of Parbati Valley geothennal discharges, north-west Himalaya. India. Geothermics, 12, 199-222.

Gökgöz, A., Mutlu, H., Özkul, M. \& Yüksel, A. K. (2021). Multiple fluid-mineral equilibria approach to constrain the evolution of thermal waters in the 
Hisaralan geothermal field, Simav graben, western Turkey. Turkish Journal of Earth Sciences, 30, 182203.

Greber, E. (1994). Deep circulation of $\mathrm{CO}_{2}$-rich palaeowaters in a seismically active zone (Kuzuluk/ Adapazar1, North western Turkey). Geothermics, 23(2), 151-74.

Hilton, D. R., Fischer, T. P. \& Marty, B. (2002). Noble gases and volatile recycling at subduction zones. In: D. Porcelli, C.J. Ballentine \& R. Wieler, (Eds.), Noble Gases in Geochemistry and Cosmochemistry. Reviews in Mineralogy and Geochemistry, 47(1), 319-370

IAH., (1979). Map of Mineral and Thermal Water of Europe, Scale: 1:500.000. International Association of Hydrogeologists, United Kingdom.

James, E. R., Manga, M., Rose, T. P. \& Hudson, G. B. (2000). The use of temperature and the isotopes of $\mathrm{O}, \mathrm{H}, \mathrm{C}$, and noble gases to determine the pattern and spatial extent of groundwater flow. Journal of Hydrology, 237, 100-112.

Ketin, İ. (1947). Uludağ Masifinin Jeoloji İncelemesi (Derleme No: 1930). Maden Tetkik ve Arama Enstitüsü (yayımlanmamış).

Marques, J. M., Andrade, M., Carreira, P. M., Eggenkamp, H. G. M., Graça, R. C., Aires-Barros, L. \& Da Silva, M.A. (2006). Chemical and isotopic signatures of $\mathrm{Na} / \mathrm{HCO}_{3} / \mathrm{CO}_{2}$-rich geofluids, North Portugal. Geofluids, 6(4), 273-287.

Mutlu, H. (1998). Türkiye'deki maden sularının kimyasal özellikleri ve oluşumu. Jeoloji Mühendisliği Dergisi, 53, 67-74.

Mutlu, H. (2007). Constraints on the origin of the Balikesir thermal waters (Turkey) from stable isotope $\left(\mathrm{d}^{18} \mathrm{O}, \mathrm{dD}, \mathrm{d}^{13} \mathrm{C}, \mathrm{d}^{34} \mathrm{~S}\right)$ and major-trace element compositions. Turkish Journal of Earth Sciences, 16, 13-32.

Mutlu, H. \& Güleç, N. (1998). Hydrogeochemical outline of thermal waters and geothermometry applications in Anatolia, Turkey. Journal of Volcanology and Geothermal Research, 85, 495-515.

Okay, A. I. (1987). Notes on the geology of Northwest Turkey. Guide book on the geology of the western Anatolia for the IGCP Project number five. Maden Tetkik ve Arama Enstitüsü.

Okay, A. I. (1989). Tectonic unit sand sutures in the Pontides, northern Turkey. In A. M. C. Şengör, (Ed.), Tectonic Evolution of the Tethyan Region (pp. 109-115). Kluwer, Dordrecht.

Okay, A. I., Harris, N. B. W. \& Kelley, S. P. (1998). Exhumation of blueschists along a Tethyan suture in North West Turkey. Tectonophysics, 285, 275299.
Parlaktuna, M., Güçer, Ş., Güleç, N., Savaşçın, Y., Mutlu, H., Tut, F. S., Erhan, Z., Süer, S., Arkan, S., Gök, E. \& Çetinoğlu, A. (2008). Geothermal Energy Potential Assessment of Bursa, Turkey (102Y156). TÜBITAK - JULICH (yayımlanmamış).

Piper, A. (1944). A graphic procedure in the geochemical interpretation of water-analyses. Transactions. American Geophysical Union. 25(6): 914-928.

Schoeller, H. (1962). Les Eaux Souterraines, Hydrologie Dynamique et Chimique, Recherche, Exploitation et Évaluation des Ressources. Masson et Cie, Paris.

Schürch, M., Kozel, R., Schotterer, U. \& Tripet, J-P. (2003). Observation of isotopes in the water cycle - the Swiss National Network (NISOT). Environmental Geology, 45, 1-11.

Stumm, W. \& Morgan, J. J. (1981). Aquatic Chemistry, an Introduction Emphasizing Chemical Equilibria in Natural Waters, 2nd ed. Wiley-Interscience, New-York.

Süer, S., Güleç, N., Mutlu, H., Hilton, D. R., Çifter, C. \& Sayı, M. (2008). Geochemical monitoring of geothermal waters (2002-2004) along the North Anatolian Fault Zone, Turkey: spatial and temporal variations and relationship to seismic activity. Pure and Applied Geophysics, 165, 17-43.

Şaroğlu, F., Emre, Ö. \& Boray, A. (1987). Türkiye'nin diri faylart ve depremselliğ (Derleme No: 8174). Maden Tetkik ve Arama Genel Müdürlüğü (yayımlanmamış).

Şengör, A. M. C. \& Yilmaz, Y., 1981. Tethyan evolution of Turkey: a plate tectonic approach. Tectonophysics, $75,181-241$.

Şentürk, N. (2006). Uludă̆ Maden Suyu Kaynakları Jeoloji-Hidrojeoloji Incelemesi ve Koruma Alanları Çalışması. Uludağ İçecek Türk A.Ş. (yayımlanmamış).

Truesdell, A. (1991). Effects of physical processes on geothermal fluids. In F. D'Amore, (coordinator), Applications of Geochemistry in Geothermal Reservoir Development. (71-92). UNITAR/UNDP Publications.

Truesdell, A. H., Nathenson, M. \& Rye, R. O. (1977). The effects of subsurface boiling and eilution on the isotopic compositions of Yellowstone thermal waters. Journal of Geophysical Research, 82, 3964-3707.

Tut Haklıdır, F. S. (2007). Bursa İli ve Çevresindeki Termal, Maden ve Yeraltı Sularının Jeokimyasal Incelenmesi [Yayımlanmamış yüksek lisans tezi]. Dokuz Eylül Üniversitesi Fen Bilimleri Enstitüsü.

Tut Haklıdır, F., 2013. Hydrogeochemical evaluation of thermal, mineral and cold waters between Bursa city and Mount Uludağ in the South Marmara region of Turkey. Geothermics, 48, 132-145. 